\title{
Adjuvant Systemic Therapy of Breast Cancer
}

\author{
Florian Schuetz \\ Department of Gynecology and Obstetrics, Heidelberg University Hospital, Germany
}

\author{
Keywords \\ Breast cancer - Adjuvant therapy · Chemotherapy · \\ Endocrine therapy
}

\section{Summary}

The first procedure in primary breast cancer is usually the surgical excision of the tumor. However, a medical therapy is necessary in almost all patients to treat the systemic component of the disease. Which medical approach is recommended depends on the biology of the tumor itself. Endocrine-responsive tumors must be treated by an endocrine therapy according to their menopausal status. In HER2/neu-overexpressing tumors, the monoclonal antibody trastuzumab is part of the standard treatment in combination with chemotherapy. Hormone receptor-negative and non-HER2/neu-overexpressing tumors as well as endocrine-responsive tumors with a high proliferation index or additional risk factors must be treated with chemotherapy as well. This review article gives further information about the available agents and schedules.

\section{Introduction}

In the majority of primary breast cancer patients, surgical tumor excision is the first step of tumor therapy as surgical excision has the largest impact on local tumor control. However, both surgery and radiation therapy are local treatments and do not consider the systemic component of the disease. Therefore, systemic medical therapies are required to further improve the patient's prognosis with regard to disease-free and overall survival. Chemotherapy and endocrine treatment have both shown an improvement in disease-free and overall survival. The Early Breast Cancer Trialists' Collaborative Group has found an advantage of polychemotherapy for

\author{
Schlüsselwörter \\ Brustkrebs - Adjuvante Therapie - Chemotherapie . \\ Endokrine Therapie
}

\section{Zusammenfassung}

Die Tumorexzision ist in der Regel der erste Schritt, frühen Brustkrebs zu behandeln. Der systemischen Komponente der Erkrankung wird durch eine medikamentöse Therapie bei nahezu allen Patientinnen Rechnung getragen. Welche Medikamente zum Einsatz kommen, hängt von der Tumorbiologie der Mammakarzinomzellen ab. Hormonabhängige Tumoren werden antihormonell (endokrin) behandelt. HER2/neu überexprimierende Tumoren werden in Kombination mit einer Chemotherapie mit dem monoklonalen Antikörper Trastuzumab behandelt. Bei Hormonrezeptor-negativen und HER2/neu normal exprimierenden Tumoren sowie Hormonrezeptor-positiven Tumoren mit hohem Proliferationsindex oder anderen Risikofaktoren ist ebenfalls eine Chemotherapie indiziert. Dieser Übersichtsartikel gibt weitere Informationen über die zur Verfügung stehenden Medikamente und Schemata. patients younger than 50 years of $12 \%$, and of endocrine therapy of $12 \%$, as well as for patients older than 50 years with endocrine-responsive disease, with regard to disease-free survival with a follow-up time of 15 years [1]. In HER2/neu-overexpressing breast cancer there is an even larger benefit for patients treated with adjuvant chemotherapy in combination with the antibody trastuzumab (approximately 43\% less relapses in comparison to polychemotherapy alone [2]).

However, there is still a need for defining who has to be treated in which concrete way and for how long.

\section{KARGER \\ Fax +497614520714 \\ Information@Karger.de}

www.karger.com (c) 2011 S. Karger GmbH, Freiburg

$1661-3791 / 11 / 0063-0179 \$ 38.00 / 0$

Accessible online at:

www.karger.com/brc 


\section{Predicitve Factors}

International guidelines - such as those of the National Comprehensive Cancer Network (USA) [3], the St. Gallen Consensus Meeting (Europe/USA) [4], and the 'Arbeitsgemeinschaft für Gynäkologische Onkologie’ (AGO, Germany) [5] - recommend the treatment of breast cancer patients according to tumor biology and not relating to tumor stage. Unfortunately, there are only a few predictive factors for defining breast cancer therapy: the presence of the estrogen receptor (ER) $\alpha$ and the progesterone receptor $(\mathrm{PgR})$ for indicating endocrine therapy; the menopausal status for indicating ovarian ablation (premenopausal) and aromatase inhibitor therapy (postmenopausal); HER2/neu overexpression for indicating trastuzumab therapy. As you may have noted there is no predictive factor available that indicates the use of chemotherapy, although some factors are under clinical investigation, like urokinase-type plasminogen activator/plasminogen activator inhibitor type 1 (uPA/PAI-1) [6] and gene expression profiles (Oncotype DX ${ }^{\circledR}$, Genomic Health, Redwood City, CA, USA [7], MammaPrint ${ }^{\circledR}$, Trommsdorff GmbH \& Co. KG, Alsdorf, Germany [8]). However, until now, only retrospective data about gene expression profiles are available which promise an excellent differentiation of a special subset of patients who do not benefit from chemotherapy. Unfortunately, in these trials there is also a large subgroup of patients with an unknown risk situation in which recommendations about chemotherapy can hardly be given. uPA and PAI-1 have both shown predictive value in a prospective German trial regarding the decision whether to recommend cyclophosphamide/methotrexate/5-fluorouracil (CMF) chemotherapy to optimize disease-free survival [9]. These data are reviewed in a larger trial with an even more effective chemotherapy regimen (Node-Negative Breast Cancer (NNBC)-3; not yet published).

Since there is a lack of targets in triple-negative breast cancer so far, chemotherapy is indicated as the only possible way of medical treatment in a patient cohort with bad prognosis [10].

\section{Chemotherapy}

Chemotherapy is indicated in patients with a high risk of relapse, as in patients with triple-negative, HER2/neu-like and luminal-B tumors with high proliferation indices [5]. In primary breast cancer, anthracyclines and taxanes have been shown to be the most effective agents in multiple trials. However, the old CMF regimen may still be an option in elderly patients [5]. The effort to optimize cytostatic treatment by including capecitabine did not show conclusive results [11]. On the one hand, capecitabine may be of benefit in extended disease [12]. On the other hand, it induces severe toxicity leading to a higher discontinuation rate. Therefore, capecita- bine should not be used as standard treatment in early breast cancer. It is important to keep in mind that only the recommended dosages promise a maximum benefit for treated patients (Level of Evidence (LoE) 1a).

\section{Anthracycline-Based Regimens}

Anthracyclines have proven to be the basic agents of an adjuvant polychemotherapy [5]. They can be combined with cyclophosphamide, 5-fluorouracil, paclitaxel, and docetaxel. The cumulative dosage has to be $20 \mathrm{mg} / \mathrm{m}^{2}$ per week for doxorubicin and higher than $30 \mathrm{mg} / \mathrm{m}^{2}$ per week for epirubicin. Anthracycline-based, taxane-free regimens like the French FEC (6 cycles of 5-fluorouracil, epirubicin $100 \mathrm{mg} / \mathrm{m}^{2}$, cyclophosphamide; q3w) or the Canadian CEF (6 cycles of cyclophosphamide, epirubicin $120 \mathrm{mg} / \mathrm{m}^{2}, 5$-fluorouracil; q3w) are indicated mainly in node-negative disease with no or only a few risk factors (proliferation indices, uPA, PAI-1, lymphangiosis, and hemangiosis carcinomatosa).

\section{Taxane-Based Regimens}

Combination chemotherapy with taxanes [5] has shown advantages in disease-free and overall survival in node-positive breast cancer (LoE 1a, GR A) [13]. However, patients with node-negative breast cancer plus additional risk factors like high-grade tumors may also benefit from taxane-based chemotherapy (LoE 2b, GR B) [14]. The optimum schedule seems to be a weekly application of paclitaxel $\left(80 \mathrm{mg} / \mathrm{m}^{2}\right)$ or a 3 -weekly one of docetaxel $\left(100 \mathrm{mg} / \mathrm{m}^{2}\right)$ [15]. The AGO guidelines recommend the following schedules:

- 6 cycles of docetaxel $75 \mathrm{mg} / \mathrm{m}^{2}$, doxorubicin $50 \mathrm{mg} / \mathrm{m}^{2}$, cyclophosphamide, q3w

- 3 cycles of 5-fluorouracil, epirubicin $100 \mathrm{mg} / \mathrm{m}^{2}$, cyclophosphamide, $\mathrm{q} 3 \mathrm{w}$; followed by 3 cycles of docetaxel $100 \mathrm{mg} / \mathrm{m}^{2}$ (q3w)

- 3 cycles of epirubicin $90 \mathrm{mg} / \mathrm{m}^{2}$ or doxorubicin $60 \mathrm{mg} / \mathrm{m}^{2}$, cyclophosphamide, $\mathrm{q} 3 \mathrm{w}$; followed by 3 cycles of docetaxel $100 \mathrm{mg} / \mathrm{m}^{2}$ (q3w) or 3 cycles of paclitaxel $80 \mathrm{mg} / \mathrm{m}^{2}$ (q1w)

Although some anthracycline-free regimens have shown some efficacy, they should not be taken as standard because the control regimens within the trials were insufficient [16].

\section{Dose-Dense and Dose-Escalated Chemotherapy}

For primary breast cancer patients with nodal involvement ( $>4$ affected lymph nodes) and consecutive extremely high risk of relapse, a dose-dense and dose-escalated chemotherapy can be of benefit in comparison to the standard regimen [17]. Both disease-free and overall survival were significantly improved after 3 cycles of epirubicin $\left(150 \mathrm{mg} / \mathrm{m}^{2}, \mathrm{q} 2 \mathrm{w}\right)$ followed by 3 cycles of paclitaxel $\left(225 \mathrm{mg} / \mathrm{m}^{2}, \mathrm{q} 2 \mathrm{w}\right)$ and 3 cycles of cyclophosphamide $\left(2500 \mathrm{mg} / \mathrm{m}^{2}, \mathrm{q} 2 \mathrm{w}\right)$, in comparison to 4 cycles of epirubicin/cyclophosphamide $\left(90 \mathrm{mg} / \mathrm{m}^{2}, 600 \mathrm{mg} /\right.$ $\left.\mathrm{m}^{2}, \mathrm{q} 3 \mathrm{w}\right)$ followed by 4 cycles of paclitaxel $\left(175 \mathrm{mg} / \mathrm{m}^{2}, \mathrm{q} 3 \mathrm{w}\right)$. However, the hematological toxicity was more severe in those patients and therefore only experienced centers should use 
this regimen. Other dose-dense regimens were also able to show superiority in comparison to the standard treatment and may be chosen in node-positive disease (doxorubicin + cyclophosphamide $(\mathrm{AC})=>$ dd paclitaxel $\mathrm{q} 1 \mathrm{w} \times 12$ [18]; ddE120C830, q2w $\times 6=>$ paclitaxel, $q 3 \mathrm{w} \times 4$ [19]).

\section{Side Effects and Supportive Therapy}

The most severe toxicity of anthracyclines is their negative effect on heart muscle cells, leading to a reduction of the left ventricular ejection fraction. Therefore, clinical and ultrasound examinations should be done before and after chemotherapy [20]. Anthracycline-free combinations (e.g. taxanes/ cyclophosphamide) have shown effectivity but were unfortunately tested against suboptimal regimens.

Taxanes have 2 main side effects. First, their hematological toxicity may require supportive treatment with colony growth-stimulating factors. Second, their neurologic toxicity may cause polyneuropathy, which is a side effect that can hardly be treated [21].

\section{Neoadjuvant (Primary) Chemotherapy}

In large tumors that cannot be treated by surgical procedure, it is reasonable to do chemotherapy first to reduce the tumor size and, subsequently, to allow surgical treatment. In the National Surgical Adjuvant Breast and Bowel Project (NSABP) B18 trial, it was shown that there is no difference regarding disease-free and overall survival if chemotherapy is applied before or after surgery [22]. Especially high-grade tumors with negative $\mathrm{ER} / \mathrm{PgR}$ status seem to benefit from neoadjuvant chemotherapy. In neoadjuvant chemotherapy, the same regimens as in the adjuvant setting should be used [23].

Nowadays, neoadjuvant chemotherapy is also employed in clinical trials to observe the efficacy of new agents by evaluating the completeness of histologic remission as a surrogate marker for overall survival.

\section{Endocrine Treatment}

In ER-positive breast cancer, tumor cells proliferate upon activation by estrogens. Estrogens bind to the cytoplasmatic $\mathrm{ER} \alpha$, leading to dimerization of ERs. Activated dimerization complexes enter the nucleus and activate ER-related genes, leading to tumor cell proliferation. However, in addition to this genomic effect, ERs seem to influence other molecular pathways like epidermal growth factor receptor (EGFR) signaling, which can induce tumor cell proliferation [24]. Whether EGFR pathways are the major mechanism of endocrine resistance is investigated in some new treatment strategies combining endocrine treatment with inhibitors of EGFR pathways to overcome endocrine resistance (e.g. mammalian target of rapamycin (mTOR) inhibitors).

Endocrine therapy is one of the most successful systemic therapies in ER-positive breast cancer. In this context, the oldest endocrine strategy is surgical ovarian ablation in premenopausal patients. However, this strategy should not be called standard of care any more, although in patients with hereditary breast cancer salpingo-ovariectomy can still be reasonable.

\section{Whom Do We Have to Treat?}

According to international guidelines, patients should be treated with endocrine therapy if ERs are expressed in more than $10 \%$ of the tumor cells. This immunohistological examination of tumor cells is still the gold standard, with false-negative results $<5 \%$, at least in countries using a standardized quality program. However, in the near future there will be a change toward tumor cell genotyping in the analysis of tumor cell responsiveness to endocrine therapy.

\section{What Is the Optimum Treatment Strategy?}

Tamoxifen as a 'selective estrogen receptor modulator' (SERM) binds to ERs as well as to PgRs in hormone receptor-positive cells. In some of these cells, it has an inhibitory action (e.g. breast cancer cells), but in others it shows stimulatory effects. Aromatase inhibitors represent an important advance in endocrine therapy of breast cancer. The oral agents ananstrozole, letrozole, and exemestane are of comparable antitumor efficacy with similar side effects [25]. Aromatase inhibitors are strictly restricted to postmenopausal patients as they can stimulate ovarian hormonal activity. Although cytochrome P450 2D6 (CYP2D6) polymorphism seems to be a predictor for defining endocrine treatment strategy [26], in this respect a recent metaanalysis did not show any beneficial effect [27].

In premenopausal women, tamoxifen is the agent of choice to treat endocrine-responsive primary breast cancer over a time period of 5 years. In high-risk patients younger than 40 years, an additional medical ovarian ablation (e.g. goserelin) after chemotherapy may be reasonable for optimizing disease-free survival. However, in patients older than 40 years, ovarian ablation may not be of benefit [5]. In lowto medium-risk patients without a need of chemotherapy, ovarian ablation may be beneficial, especially in patients with high ER expression [28].

In postmenopausal patients, a tamoxifen monotherapy for 5 years is not standard of care anymore, but may still be indicated in patients with contraindications against aromatase inhibitors [29]. Sequential treatment with tamoxifen and an aromatase inhibitor seems to be the optimum strategy, by balancing risks and benefits for the patients. The classic switch of 2-year tamoxifen to an aromatase inhibitor has been well investigated in several trials [29]. However, in node-positive patients, it seems reasonable to start with an aromatase inhibitor for 2 years and then to switch to tamoxifen for another 3 years according to the Breast International Group (BIG) 1-98 trial [30]. A 5-year treatment with aromatase inhibitors is reasonable particularly in patients in whom tamoxifen is 
contraindicated, although it is accompanied by several toxicities like 'cancer therapy-induced osteoporosis' and myalgia/ arthralgia [5].

\section{What is the Optimum Duration of Endocrine Treatment?}

The reason why endocrine treatment should last 5 years is based on older studies of tamoxifen administration. In these trials, a longer tamoxifen treatment resulted in a significantly better breast cancer-specific survival but showed markedly increased side effects, like a higher incidence of endometrial cancer and thromboembolic events [31].

On the other hand, an extended endocrine treatment with aromatase inhibitors after pretreatment with tamoxifen over 5 years has been investigated in several trials [25]. Especially in patients with primary premenopausal status in whom 5 years of tamoxifen are indicated and who develop postmenopausal status under tamoxifen there seems to be a significant benefit [32]. Furthermore, patients with initially node-positive disease obviously do benefit from this extended endocrine treatment [25]. However, primary extension of endocrine therapy is rarely discussed by experts in postmenopausal patients due to the higher risk of recurrence within the first 5 years of tamoxifen in comparison to an aromatase inhibitor-containing treatment.

\section{Open Questions}

Admittedly, although we have made some important advances in treating breast cancer systemically, some open questions still remain:

- Are anthracycline-free regimens comparable to anthracycline-containing ones?

- Is there a possibility of protecting the heart against the negative effects of anthracyclines?

- Who benefits most from endocrine treatment?

- How can we treat endocrine resistance?

- Is a longer time period of endocrine treatment with aromatase inhibitors reasonable in patients who already received aromatase inhibitors in the previous 5 years?

Many trials have already been done and maybe we can answer some of the above questions by having a closer look into these trials. However, in the future, targeted systemic treatment of breast cancer according to defined predictive factors will be the key to optimize overall survival step by step.

\section{Disclosure Statement}

The author received lecture honoraria from Novartis Oncology, Sanofi-Aventis, Amgen, and Hoffmann-LaRoche.

\section{References}

1 Early Breast Cancer Trialists' Collobarative Group (EBCTCG): Effects of chemotherapy and hormonal therapy for early breast cancer on recurrence and 15-year survival: an overview of the randomised trials. Lancet 2005;365:1687-1717.

2 Jahanzeb M: Adjuvant trastuzumab therapy for HER2-positive breast cancer. Clin Breast Cancer 2008;8:324-333.

3 www.nccn.org/professionals/physician_gls/f_guidelines.asp.

${ }_{4}$ Goldhirsch A, Ingle JN, Gelber RD, Coates AS, Thürlimann B, Senn HJ; panel members: Thresholds for therapies: highlights of the St Gallen International Expert Consensus on the primary therapy of early breast cancer 2009. Ann Oncol 2009;20:1319-1329.

5 www.ago-online.org

6 Annecke K, Schmitt M, Euler U, Zerm M, Paepke D, Paepke S, von Minckwitz G, Thomssen C, Harbeck N: uPA and PAI-1 in breast cancer: review of their clinical utility and current validation in the prospective NNBC-3 trial. Adv Clin Chem 2008;45:31-45.

$\checkmark 7$ Ademuyiwa FO, Miller A, O'Connor T, Edge SB, Thorat MA, Sledge GW, Levine E, Badve S: The effects of oncotype DX recurrence scores on chemotherapy utilization in a multi-institutional breast cancer cohort. Breast Cancer Res Treat 2011;126:797-802

8 Tian S, Roepman P, Van't Veer LJ, Bernards R, de Snoo F, Glas AM: Biological functions of the genes in the mammaprint breast cancer profile reflect the hallmarks of cancer. Biomark Insights 2010;28:129-138.
9 Jänicke F, Prechtl A, Thomssen C, Harbeck N, Meisner C, Untch M, Sweep CG, Selbmann HK, Graeff H, Schmitt M; German N0 Study Group: Randomized adjuvant chemotherapy trial in highrisk, lymph node-negative breast cancer patients identified by urokinase-type plasminogen activator and plasminogen activator inhibitor type 1. J Natl Cancer Inst 2001;93:913-920.

10 Yagata H, Kajiura Y, Yamauchi H: Current strategy for triple-negative breast cancer: appropriate combination of surgery, radiation, and chemotherapy. Breast Cancer 2011, in press.

11 Joensuu H, Kellokumpu-Lehtinen P-L, Huovinen R, Jukkola-Vuorinen A, Tanner M, Kokko R, Ahlgren J, Auvinen P, Bono P, Lindman H; FinXX study investigators: Final 5-year analysis: results of the randomised, open-label, phase III trial in medium-to-high risk early breast cancer. www.abstracts2view.com/sabcs10/view.php?nu= SABCS10L_564.

12 O'Shaughnessy J, Paul D, Stokoe C, Pippen J Jr, Blum JL, Krekow L, Holmes FA, Vukelja S, Lindquist D, Sedlacek S, Rivera R, Brooks R, McIntyre K, Pluenneke R, Schwartz J, Jones S, Brownstein C, Gilberg F: First efficacy results of a randomized, open-label, phase III study of adjuvant doxorubicin plus cyclophosphamide, followed by docetaxel with or without capecitabine, in highrisk early breast cancer. www.abstracts2view.com/ sabcs10/view.php? nu=SABCS10L_954.

13 Bedard PL, Di Leo A, Piccart-Gebhart MJ: Taxanes: optimizing adjuvant chemotherapy for early-stage breast cancer. Nat Rev Clin Oncol 2010;7:22-36.
14 Martin M, Iluch A, Segui A, Ruiz A, Ramos A, Adrover Cebrián E, Rodriguez-Lescure A, Grosse R, Calvo Martínez L, Anton A: Multicenter, randomized phase III study of adjuvant chemotherapy for high-risk, node-negative breast cancer comparing TAC with FAC: 5-year efficacy analysis of the GEICAM 9805 trial. J Clin Oncol 2008;26(suppl):abstr 542.

15 Sparano JA, Wang M, Martino S, Jones V, Perez EA, Saphner T, Wolff AC, Sledge GW Jr, Wood WC, Davidson NE: Weekly paclitaxel in the adjuvant treatment of breast cancer. N Engl J Med 2008;358:1663-1671.

16 Jones S, Holmes FA, O'Shaughnessy J, Blum JL, Vukelja SJ, McIntyre KJ, Pippen JE, Bordelon JH, Kirby RL, Sandbach J, Hyman WJ, Richards DA, Mennel RG, Boehm KA, Meyer WG, Asmar L, Mackey D, Riedel S, Muss H, Savin MA Docetaxel with cyclophosphamide is associated with an overall survival benefit compared with doxorubicin and cyclophosphamide: 7-year followup of US Oncology Research Trial 9735. J Clin Oncol 2009;27:1177-1183.

17 Untch M, Möbus V, Kuhn W, Muck BR, Thomssen C, Bauerfeind I, Harbeck N, Werner C, Lebeau A, Schneeweiss A, Kahlert S, von Koch F, Petry KU, Wallwiener D, Kreienberg R, Albert US, Lück HJ, Hinke A, Jänicke F, Konecny GE: Intensive dosedense compared with conventionally scheduled preoperative chemotherapy for high-risk primary breast cancer. J Clin Oncol 2009;27:2938-2945. 
18 Sparano JA, Wang M, Martino S, Jones V, Perez EA, Saphner T, Wolff AC, Sledge GW Jr, Wood WC, Davidson NE: Weekly paclitaxel in the adjuvant treatment of breast cancer. N Engl J Med 2008;358:1663-1671.

19 Burnell M, Levine M, Chapman JA, Bramwell V, Gelmon K, Walley B, Whelan T, Albain K, Perez E, Rugo H, Ding Z, O'Brien P, Shepherd $\mathrm{L}$, Pritchard K: A randomized trial of $\mathrm{CEF}$ versus dose dense EC followed by paclitaxel versus AC followed by paclitaxel in women with node positive or high risk node negative breast cancer, NCIC CTG MA.21: results of an interim analysis. San Antonio Breast Cancer Symposium, 2006.

20 Broeyer FJ, Osanto S, Ritsema van Eck HJ, van Steijn AQ, Ballieux BE, Schoemaker RC, Cohen AF, Burggraaf J: Evaluation of biomarkers for cardiotoxicity of anthracyclin-based chemotherapy. J Cancer Res Clin Oncol 2008;134:961-968.

21 Swain SM, Arezzo JC: Neuropathy associated with microtubule inhibitors: diagnosis, incidence, and management. Clin Adv Hematol Oncol 2008;6:455-467.

-22 Fisher B, Brown A, Mamounas E, Wieand S, Robidoux A, Margolese RG, Cruz AB Jr, Fisher ER, Wickerham DL, Wolmark N, DeCillis A, Hoehn JL, Lees AW, Dimitrov NV: Effect of preoperative chemotherapy on local-regional disease in women with operable breast cancer: findings from National Surgical Adjuvant Breast and Bowel Project B-18. J Clin Oncol 1997;15:2483-2493.

23 von Minckwitz G, Kümmel S, Vogel P, Hanusch C, Eidtmann H, Hilfrich J, Gerber B, Huober J, Costa SD, Jackisch C, Loibl S, Mehta K, Kaufmann M; German Breast Group: Intensified neoadjuvant chemotherapy in early-responding breast cancer: phase III randomized GeparTrio study. J Natl Cancer Inst 2008;100:552-562.
24 Al Saleh S, Sharaf LH, Luqmani YA: Signalling pathways involved in endocrine resistance in breast cancer and associations with epithelial to mesenchymal transition (Review). Int J Oncol 2011;38:1197-1217.

25 Goss PE, Ingle JN, Pater JL, Martino S, Robert NJ, Muss HB, Piccart MJ, Castiglione M, Shepherd LE, Pritchard KI, Livingston RB, Davidson NE, Norton L, Perez EA, Abrams JS, Cameron DA, Palmer MJ, Tu D: Late extended adjuvant treatment with letrozole improves outcome in women with early-stage breast cancer who complete 5 years of tamoxifen. J Clin Oncol 2008;26:19481955.

26 Schroth W, Hamann U, Fasching PA, Dauser S, Winter S, Eichelbaum M, Schwab M, Brauch H: CYP2D6 polymorphisms as predictors of outcome in breast cancer patients treated with tamoxifen: expanded polymorphism coverage improves risk stratification. Clin Cancer Res 2010;16:4468-4477.

27 Lash TL, Cronin-Fenton D, Ahern TP, Rosenberg CL, Lunetta KL, Silliman RA, Garne JP, Sørensen HT, Hellberg Y, Christensen M, Pedersen L, Hamilton-Dutoit S: CYP2D6 inhibition and breast cancer recurrence in a population-based study in Denmark. J Natl Cancer Inst 2011;103:489-500.

28 Sverrisdottir A, Johansson H, Johansson U, Bergh J, Rotstein S, Rutqvist LE, Fornander T: Interaction between goserelin and tamoxifen in a controlled clinical trial of adjuvant endocrine therapy in premenopausal breast cancer. $w w w$.abstracts2view.com/sabcs10/view.php?nu=SABCS10L_981.
9 Dowsett M, Cuzick J, Ingle J, Coates A, Forbes J, Bliss J, Buyse M, Baum M, Buzdar A, Colleoni M, Coombes C, Snowdon C, Gnant M, Jakesz R, Kaufmann M, Boccardo F, Godwin J, Davies C, Peto R: Meta-analysis of breast cancer outcomes in adjuvant trials of aromatase inhibitors versus tamoxifen. J Clin Oncol 2010;28:509-518.

30 Viale G, Regan MM, Dell'orto P, Mastropasqua MG, Maiorano E, Rasmussen BB, Macgrogan G, Forbes JF, Paridaens RJ, Colleoni M, Láng I, Thürlimann B, Mouridsen H, Mauriac L, Gelber RD, Price KN, Goldhirsch A, Gusterson BA, Coates AS; for the BIG 1-98 Collaborative and International Breast Cancer Study Groups: Which patients benefit most from adjuvant aromatase inhibitors? Results using a composite measure of prognostic risk in the BIG 1-98 randomized trial. Ann Oncol 2011, in press.

31 Gray RG, Rea DW, Handley K, Marshall A, Pritchard MG, Perry P, Earl HM, Poole CJ, Salman A, Lee M, aTTom Collaborators, aTTom (adjuvant Tamoxifen - To offer more?): Randomized trial of 10 versus 5 years of adjuvant tamoxifen among 6,934 women with estrogen receptor-positive $(\mathrm{ER}+)$ or ER untested breast cancer - preliminary results. J Clin Oncol 2008;26(suppl):abstr 513.

-32 Goss P, Ingle J, Martino S, Robert N, Muss H, Shepherd L, Pritchard K, Livingston R, Davidson N, Perez E, Cameron D, Whelan T, Palmer M, Tu D: Outcomes of women who were premenopausal at diagnosis of early stage breast cancer in the NCIC CTG MA17 trial. Cancer Res 2009;69(suppl):abstr 13. 